\title{
Analysis of the influence of word of mouth and brand image on the decision to purchase cosmetics make over products in Semarang
}

\section{Nurul Imani Kurniawati}

Vocational Schools, Diponegoro University, Indonesia

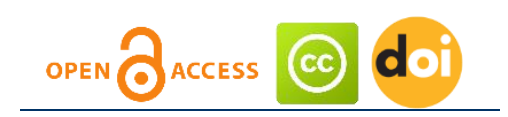

Article history:

Received: July 10, 2020

1st Revision: August 23,

2020

Accepted: October 31,

2020

\section{JEL classification: \\ M31}

M37

\section{DOI:}

10.14254/jems.2020.5-2.11

\begin{abstract}
Increased the awareness of women to beautify themselves with the use of make-up. These become a reason why the growth of industrial cosmetics in Indonesia is growing fast, and one of them is Make Over Cosmetic. This study aimed to determine the effect of word of mouth and brand image on purchase decision of Make over's cosmetic. The type of the research is explanatory research and the sampling used nonprobability sampling techniques, and purposive sampling method. Data collection using questionnaires and Google form. The sample is used amount 100 respondents using Make Over products in Semarang City. This study used quantitative and qualitative analysis with validity, reliability, correlation coefficients, coefficient of determination, and simple regression, significance that is processes using SPSS. The result of the study shows that the variables of word of mouth and brand image have an effect on purchase decisions. The variable correlation coefficient of word of mouth and brand image on purchase decisions have a very strong enough relation, and if the variables of word of mouth and and brand image have increased or decreased it is greatly affected the purchase decision variable.
\end{abstract}

Keywords: word of mouth, brand image, purchase decisions, customer behavior, cosmetic.

\section{Introduction}

Increased the awareness of women to beautify themselves with the use of the series of cosmetics and facial treatments, resulting in many cosmetics companies that competing to offer their products aggressively with vary of products and prices types, with the aim of attracting consumers, especially for female consumers. This is proven by the rapid increase of cosmetics industry in Indonesia. Based on data from the Ministry of Industry through the survey conducted by BIZTEKA

Corresponding author: Nurul Imani Kurniawati

E-mail: niyanurulimanii@gmail.com

This open access article is distributed under a Creative Commons Attribution (CC-BY) 4.0 license. 
CCI Indonesia (2016), the average cosmetics industry market growth is reached $9.67 \%$ per year in the last six years (2009-2015).

\begin{tabular}{ccc}
$\begin{array}{c}\text { Table 1: The development of cosmetics market industry in Indonesia (2010-2015) } \\
\text { Years }\end{array}$ & Market (in trillion Rupiahs) & Increase (in \%) \\
\hline 2010 & 8,9 & - \\
2011 & 8,5 & $(-) 4,49$ \\
2012 & 9,7 & 14,82 \\
2013 & 11,2 & 14,75 \\
2014 & 12,8 & 14,95 \\
2015 & 13,9 & 8,30 \\
Average increase per year & & 9,67
\end{tabular}

Source: BIZTEKA Survey - CCI Indonesia (2016)

Whereas in the 2017, the cosmetics industry in Indonesia is experienced a growth of $20 \%$, namely an increase of 153 companies. Until now, the total of Cosmetics Company is more than 760 companies with market size cosmetics in Indonesia in 2017 has reaches IDR 46, 4 Trillion. From the total above, $95 \%$ of the national cosmetics industry is the small and medium of industry sector (IKM) and the rest is large-scale industry. The export value of national cosmetic products also increased to US \$ 16.99 million from US \$ 470.30 million in 2016 . The growth of the Indonesian beauty industry which reached four times of the national growth made the beauty industry chosen as a mainstay sector in 2015-2035 of National Industrial Development Master Plan (RIPIN). Therefore, Indonesia is the potential market for the beauty industry entrepreneurs both from foreign and domestic. (Bella, 2018) (Source: https://marketeers.com/potensi-gemuk-pasar-kosmetik-tanah-air/).

The increase in the growth of the cosmetics industry in Indonesia is inseparable from the support and efforts of the government through the Ministry of Industry (Kemenperin) to boost the local cosmetics producers to be able to compete and increase their sales internationally. This is a step of the government is trying to compete with South Korea as a market leader in the beauty world.

The greater potential of cosmetic market is also caused by some factors such as increased the awareness of women to beautify themselves through the using of Make-up, increase in the number of adolescents who are fond of preening and make-up currently becoming part of the lifestyle of Indonesian women (Indonesia-investments, 2018) (www.indonesia-investments.com, 2017).

In Indonesia, the cosmetic market is colored by local and imported players. From many of local cosmetics companies in Indonesia, Make Over is one of the cosmetic companies that have gone internationally and even its presence is often mistaken for brands originating from overseas. Make Over was founded by a cosmetics entrepreneur from Indonesia through Paragon Technology and Innovation Ltd. that produced domestically since 2003. As quoted from IDNTimes, Make Over the third ranks after the Make Over and Sensatia Botanicals products in 7 (seven) local cosmetic brands that have quality not inferior to foreign product brands. The quality of the products and packaging that used is the high quality premium materials dominated by black which make Make Over look more elegant and the color choices that offered are not the same as those of other local brands. In addition to focusing on the quality of its products, Make Over also aggressively promotes and participates in a variety of events both at home and overseas. Make Over participates as a make-up partner at the Jakarta fashion Week 2018 (JFW2018) fashion event and supports the young Indonesian fashion designers at fashion shows overseas. In 2013, Make Over received an award from Women's Health Choice Indonesia as the cosmetic brand of choice for Indonesian women.

But even so, an increase in the number of cosmetics companies in Indonesia that sell the same products as Make Over has made the competition in the cosmetics industry increasingly competitive and consumers which have many choices to decide which cosmetic brand suits their needs. Therefore, in order for Make Over to survive and continue to exist in the cosmetics industry, companies must make the various efforts to maintain and enhance their position in the market by finding ways to attract the attention of consumers, they can influence consumers' decisions in purchasing the Make Over cosmetics brand.

The desire to buy is the tendency of consumers to buy. Therefore, for companies, consumers are the important assets that must be considered for the sake of business continuity. Because consumers can determine the success of the company and reflect to the potential for sales growth in the future, the existence of consumers is expected by every company. Therefore the company must be able to pay attention exist the consumer behavior as in the case of purchasing decisions. According 
to Lamb, Hair and Mc. Daniel (Rangkuti, 2009) states that consumer behavior is a process when consumers decided to buy, use and consume the goods and services purchased, also includes the factors that influence the purchasing decisions and the use of products.

Purchasing decision is a process implemented by consumers to meet their needs in order to obtain the satisfaction with the highest value. The purchasing decision according to (Schiffman \& Kanuk, 2008) is "the selection of an options from two or alternative choices" means that the purchase decision is the decision of a person where he chooses one of the several alternative choices. Meanwhile, according to (Kotler and Keller, 2009)(Kotler, \& Amstrong, 2008), purchasing decisions are the actions of consumers to want to buy or not to product. With more companies producing and selling goods with the same function, consumers are faced with the many choices of these products, they become more selective. As in treating facial beauty, the majority of consumers are women who have many choices about what products and cosmetic brands to use that can certainly provide maximum satisfaction.

This is also experienced by the cosmetics manufacturer of Make Over, the number of cosmetic products that have the similar variances and functions resulted in Make Over having to make various efforts to attract consumers to be willing to buy their products, one of them is trying to create the word of mouth and good brand image, consumers are expected to repurchase their products in accordance with what is expected by the company, because this can affect and reflect the survival of the company through sales growth and profitability of the company. But despite many ways done by Make Over, Make Over sales growth has not been as expected by management. In Table 2 there is data on the percentage of sales growth of Make Over cosmetic products at Paragon Technology and Innovation Ltd. in 2017-2018.

\begin{tabular}{cc} 
Table 2: Sales Growth Data (in \%) & Make Over for 2016-2018 \\
\hline Year & Growth percentage of sales \\
\hline 2016 & $39.45 \%$ \\
2017 & $48.84 \%$ \\
2018 & $42.72 \%$ \\
\hline
\end{tabular}

Source: Paragon Technology and Innovation Ltd, in 2016-2018

Based on the table above it can be seen that the sales of Make Over cosmetics products in the city of Semarang in the period of 2016 - 2017 has experienced an increase in sales growth of $9.39 \%$ from $39.45 \%$ to $48.84 \%$ but in $2017-2018$ is decreased the sales growth by $6.12 \%$ from $48.84 \%$ to $42.72 \%$. This shows an indication that the decline in Indonesian women's interest towards Make Over cosmetics, especially in Semarang city in 2017 to 2018. The decline in the number of sales of Make Over products in the Semarang city can be influenced by several factors, one of them is that consumers prefer to use cosmetics from other brands that has product quality, price, image and promotions which more attractive than Make Over products. Especially if a consumer after used the product tells, recommends and positive reviews through word of mouth or through their social media accounts, it will indirectly form a positive image in the minds of the public to consume the product.

There are several factors that influence the consumer decisions regarding to purchase of products or services, such as family, product quality, price, brand, service, sale location, country of manufacture, promotion, and purchasing situation. This is important for a company in developing their marketing strategy. One of the marketing strategies adopted by the company is through the marketing communications. According to (Kotler and Armstrong, 2018) marketing communication is a means used by companies in effort to inform, persuade and remind the consumers directly or indirectly about the products or brands that they sell. To implement the marketing communication, one of them is promoting word of mouth.

(Andy Sernovitz; Seth Godin; Guy Kawaskaki, 2012) revealed that word of mouth is communication that results in good conversations. Someone will ask others about the quality of item or service before they are decide to buy it. Therefore, word of mouth can influence person's purchasing decisions to making a purchase. Through word of mouth promotion we can foster public curiosity, and because it is based on empathy, the power of word of mouth promotion is able to stop consumer complaints before they occur.

Bone in (Mowen \& Minor, 2002) also states that word of mouth communication refers to the exchange of comments, thoughts, or ideas between two or more consumers, none of which are marketing sources. Word of mouth communication has very strong influence on consumer buying behavior. Some studies suggest that Word of Mouth has a positive effect on purchasing decisions. 
"Word of mouth in consumer purchase decisions: The moderating role of product type" explains that Word of Mouth has the positive effect on Purchasing Decisions.

If the Word of Mouth was produced by consumers of a product is good, it will indirectly form a good perception and image of the product brand. (Hasan, 2010) stated that word of mouth is the act of consumers giving the information to other consumers of one person to others (between individuals, brands, products and services). If the brand image of a product is well received by consumers, of course it will make the brand is easy to remember and known in the minds of consumers.

As said by (Kotler, 2013) that brand image is usually associated with information that is in memory with something that related to the service or product. Brand image is what customers think and feel when they hear or see a brand name. A positive image of brand allows the consumers to repurchase. A better brand is also the basis for building a positive company image.

Many products have the same form, usability, and other features make it difficult for consumers to differentiate these products. Consumers will not buy products that are not in accordance with their expectations. Therefore, the companies are required to show the quality of the products they produce such as durable, different characteristics, and specifications.

In this study, there are problems there is decrease in the percentage of growth in sales of cosmetic products Make Over from 2017-2018 and there is a view of word of mouth effect and brand image on the purchasing decision to cosmetics Make Over products. Word of mouth and brand image are one of the many factors that influence consumers in making product purchasing decisions. Therefore, this study formulates the problem regarding how the influence of word of mouth and brand image on the decision to purchase cosmetic products in Semarang City.

\section{Theoretical review}

\section{Purchasing decision}

According to (Peter and Olson, 2013) purchasing decision is a process of combining knowledge to evaluate two or more alternative behaviors and choose one of them. Purchasing decisions according to (Schiffman and Kanuk, 2008) are the selection of two or more alternative purchasing decision choices, means that one can make a decision if several alternative choices are available.

The role of purchasing decisions according to (Kotler, 2011), roles in purchasing decisions, there are:

1. Originator (Initiator)

People who are the first aware of a desire or need that has not been met and propose an idea to buy a certain item or service.

2. Influencer decisions.

People who are provide views, advice, or opinions so that they can influence purchasing

3. Decision makers (Decider)

People who are make decisions about each component of the purchase decision which includes whether to buy the item or not, about how to buy it or where to buy it.

4. Buyers

People who are have formal authority to choose suppliers and compilers of purchasing terms.

\section{Users}

People who consume or use goods or services that have been purchased.

6. Approval (Approvers)

Namely people who are have the power to give approval to sales activities.

\section{Gate Keepers}

Namely people who are have the power to deter seller and information that it cannot reach the members of the purchasing center. 


\section{Word of Mouth}

(Kotler and Keller, 2009) suggested that Word of Mouth Communication (WOM) is a communication process in the form of giving recommendations both individually and groups of a product or service that aims to provide personal information.

(Andy Sernovitz; Seth Godin; Guy Kawaskaki, 2012) revealed that word of mouth is communication which results in good conversations. Someone will ask others about the quality of an item or service before they decided to buy it. Therefore, word of mouth can influence person's purchasing decisions to making a purchase. Through word of mouth promotion we can foster public curiosity, and because of its empathy-based nature, the power of word of mouth promotion is able to stop consumer complaints before they occur.

Bone in (Mowen and Minor, 2002) also states that word of mouth communication refers to the exchange of comments, thoughts, or ideas between two or more consumers, none of which are marketing sources.

Word Of Mouth is one of the company's marketing strategies that is formed indirectly and occurs among consumers. Communication is carried out in advance by someone who already has experience in using a product so that it can provide detailed information about a product strengths, and recommend products that have been used to others.

\section{Brand Image}

(Kotler, 2013) stated that brand image is usually associated with information that is in memory of something which related to the service or product. Brand image is what the customers think and feel when they hear or see a brand name. A positive image of a brand allows consumers to repurchase. A better brand is also the basis for building a positive company image. Meanwhile, according to Keller (Keller, 2008) brand image is the consumer's perception of the brand image of the product to be consumed or used.

\section{Hypothesis models}

Based on the previous study, a hypothetical model can be developed to examine the effect of Word of Mouth and Brand Image on the Purchase Decision of Make Over cosmetic products, as in Figure 1.1 as follows:

Figure 1: Hypothesis model

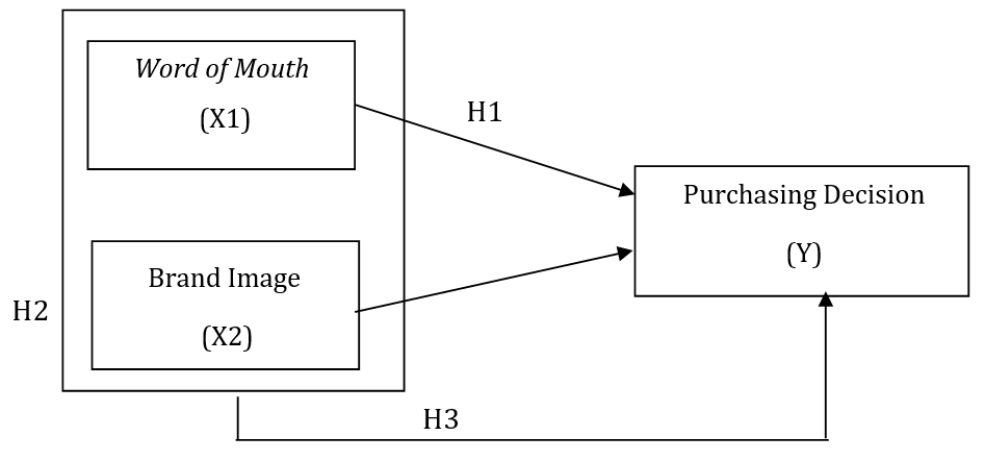

H1: Word Of Mouth (X1) influences the Purchasing Decision (Y) of Make Over cosmetic products in Semarang.

H2: Brand Image (X2) influences the Purchasing Decision (Y) of MakeOver cosmetic products in Semarang.

H3: Word Of Mouth (X1) and Brand Image (X2) influences the Purchase Decision (Y) of Make Over cosmetic products in Semarang. 


\section{Methodology}

\section{Population and analysis sample}

The population in this study is the consumers of Make Over products who are have or currently using Make Over products in the Semarang city. The sampling technique used is nonprobability sampling. The type of respondent that taking is uses accidental sampling, namely Make Over consumers who happen to be located and meet with researchers in the Semarang City area. The sampling technique is uses purposive sampling, namely the sampling technique with certain considerations (Sugiyono, 2014), including: (1) residing in the Semarang area; (2) at least 20 years old; (3) Have already bought and still using Make Over products at least twice. It is not known with certainty that the number of samples used is 100 respondents who are considered to be representative for research. According to (Cooper and Schindler, 2006), that the basic formula to determining the sample size for populations that are not precisely defined in number, the sample is determined directly by 100 respondents.

\section{Data analysis techniques}

Analysis of the data used in this study is to use simple linear regression analysis that is processed using SPSS.

\section{Result}

\section{Validity test}

Validity test is measure that shows the level of instrument's validity (measuring instrument/indicator). If the value of $r$ count $>$ from the table's $r$ value and the value of $r$ is positive, then the question item is declared valid. The statement is to be invalid if $r$ count $<$ from $r$ table. Based on the results of testing the data of the indicators that used in the variable Word of Mouth (X1), brand image (X2) and Purchase Decision (Y) it can be said that the r number is calculated on all items used to measure the variable Word of Mouth (X1), Brand Image (X2) and Purchase Decision (Y) is greater than the $r$ number table of 0.1966 or in other words $r$ count $\geq r$ table. Then all items used to measure Word of Mouth (X1), Brand Image (X2) and Purchase Decision (Y) variables are valid. This means that all indicators can be used to measure Word of Mouth (X1), Brand Image (X2) and Purchase Decision (Y) variables.

\section{Reliability test}

Reliability is a tool to measure the questionnaire which is an indicator of variables. Measuring instrument is said to be reliable if the Cronbach Alpha number exceeds 0.60 (Cronbach Alpha $>0.60$ ). Based on the results of testing the data from the indicators used in the variable Word of Mouth (X1), Brand Image (X2) and Purchase Decision (Y) it can be said that the alpha calculation results for each variable are greater than 0.60 (Cronbach alpha $\geq 0,60$ ) then, all variables in this study are stated to be reliable. This means if the indicator is asked back to the same respondent then the answer is still the same.

\section{Analysis of the effect of word of mouth on purchasing decisions}

The correlation test results in the Word of Mouth Variable on Purchasing Decisions indicates that there is a strong relationship between the word of mouth variable with the purchase decision indicated by the correlation coefficient or the level of closeness of the relationship is 0.734 (found at intervals of 0.60 to 0.799 and into the category strong correlation). Therefore, it can be said that if the word of mouth variable increases or decreases the respondent's perception, it will greatly affect the purchase decision variable. The coefficient of determination (R2) is 0.397 this means that the influence given by the word of mouth variable on purchasing decisions is $39.7 \%$, while the remaining $60.3 \%$ is influenced by other variables besides word of mouth. 
Simple linear regression analysis aims to partially examine the dependent and independent variables and to find out whether any increase or decrease in the purchase decision variable can be influenced by increase or decrease in the word of mouth variable. From the calculation results, there is a constant value of 1.316 means if the word of mouth variable is assumed to be zero (0) or there is no word of mouth variable, then the purchase decision variable based on the respondents' perceptions does not change it is equal to 1,316. Then the regression coefficient value of the word of mouth variable (X1) based on the calculation results shows a positive which is equal to 0.758 stating that the word of mouth variable has an influence on the purchase decision variable of 0.758 .

The result of this study indicates that word of mouth has a strong relationship with purchasing decisions as evidenced by the correlation coefficient of 0.734 . Therefore, it is said that if positive information is obtained by consumers who use Make Over products through word of mouth such as Make Over products are safe in the skin, smooth texture, easy to blend, and color variants that are in accordance with the wishes of consumers, then consumers will tend to make purchasing decisions on Make Over products. This is supported research was conducted by (Molinari, Abratt and Dion, 2008) stated that consumers after consuming a product will tell their experiences of the product to others, such as family and friends. If the experience in consuming products is positive, the word of mouth that is created will also positive and will encourage consumers to make purchasing decisions on a product.

\section{Analysis of the effect of brand image on purchasing decisions}

Correlation test results on brand image variables on purchasing decisions indicate that there is a strong relationship between brand image variables on purchasing decisions as indicated by value of correlation coefficient or the level of closeness of the relationship is 0.891 (found at intervals of $0.80-1.00$ and into the category correlation is very strong). The coefficient of determination (R2) is 0.742 . This means that the influence given by the brand image variable on purchasing decisions is $74.2 \%$, while the remaining $25.8 \%$ is influenced by other variables besides brand image.

The results of simple linear regression calculations, there is a constant value of 1.884 means that if the brand image variable is assumed to be zero (0) or there is no brand image variable, then the purchase decision variable based on respondents' perceptions does not change that is equal to 1.884. Then the regression coefficient value of the brand image variable (X2) based on the calculation results shows a positive that is equal to 0.785 states that the brand image variable has an influence on the purchase decision variable of 0.785 .

The result of this study indicates that brand image has very strong relationship with purchasing decisions as evidenced by the correlation coefficient of 0.891 . Therefore, it is said that brand image plays an important role in fostering of purchasing decisions for Make Over products. The results of this study are supported research was conducted by (Sagita et al., 2012; Angio, 2013; Musay, 2013; Farida and Ristiawan, 2015) that brand image has a strong and significant influence on consumer purchasing decisions. While (Schiffman and Kanuk, 2008) argue that if consumers do not have experience in consuming a product, then they will tend to choose products based on a brand they have known before.

\section{Analysis of the effect of word of mouth and brand image on purchasing decisions}

Correlation test results in the word of mouth variable and brand image to the purchase decision indicate that there is a strong relationship between the word of mouth variable and brand image to the purchase decision as indicated by the correlation coefficient or the level of the relationship is 0.825 (found at intervals of $0.80-1,00$ and included in the very strong correlation category). The coefficient of determination $\left(\mathrm{R}^{2}\right)$ is 0.783 . This means that the effect of word of mouth and brand image variables on purchasing decisions is $78.3 \%$, while the remaining $21.7 \%$ is influenced by other variables besides word of mouth and brand image.

The results of simple linear regression calculations, it can be seen that the regression coefficient for the word of mouth variable (X1) is 0.253 and the regression coefficient for the brand image variable (X2) is 0.406 and for the constant value is -1.653 . Based on these equations it can be interpreted that between the word of mouth and brand image variables on purchasing decisions together has positive effect, this is based on the value of the regression coefficient is positive. While 
the constant value of -1.673 greater than the $Y$ value in the equation of -0.578 states that the word of mouth and brand image variables influence the purchase decision and it can be seen that the most dominant variable in this study is the brand image variable seen in the standardized coefficients column, beta which is equal to 0.506 .

\section{Discussion}

\section{Analysis of the effect of word of mouth on purchasing decisions}

The result of data analysis shows that word of mouth has strong relationship with purchasing decisions as evidenced by the correlation coefficient of 0.734 . Therefore, it is said that if positive information is obtained by consumers who use Make Over products through word of mouth such as Make Over products are safe in the skin, smooth texture, easy to blend, and color variants that are in accordance with the wishes of consumers, then the consumers will tend to make purchasing decisions for Make Over products. This is supported research was conducted by (Nuraeni, 2014; Moniharapon, Lapian and Lotulung, 2015; Joesyiana, 2018) that word of mouth has a significant effect on consumer purchasing decisions, which means that Word of mouth has a positive contribution to consumer purchasing decisions. (Wicaksono and Seminari, 2016) also stated that advertising and word of mouth had a positive and significant effect on Traveloka's brand awareness. Therefore, advertising and word of mouth dominant or most influential on purchasing decisions.

\section{Analysis the influence of brand image on purchasing decision}

The results of data analysis show that brand image has very strong relationship with purchasing decisions as evidenced by the correlation coefficient of 0.891 . Therefore, it is said that brand image plays an important role to fostering of purchasing decisions for Make Over products. In accordance with research presented by (Simbolon, 2015; Tampinongkol and Mandagie, 2018) that brand image has strong and significant influence on consumer purchasing decisions. The results of this study are also supported by research conducted by (Amrullah and Agustin, 2016) that partially, brand image has a significant effect on purchasing decisions because good quality can lead to increased sales and improved company image in the eyes of the public. While (Schiffman and Kanuk, 2008) argue that if consumers do not have experience in consuming a product, then they will tend to choose products based on the brand that they have known before.

\section{The analysis of word of mouth effect and brand image on purchasing decision}

The results of data analysis showed that word of mouth and brand image have very strong relationship with purchasing decisions as evidenced by the correlation coefficient of 0.891 . Therefore, it is said that if consumers after using a product tell, recommend and positive review of their experience to consuming the product through word of mouth or through their social media accounts, it will indirectly form positive image in the minds of the public to consume the product. With a strong positive image, it will influence consumers to make repeat purchases and bring a new consumer to participate in trying the product.

The brand image, price and word of mouth simultaneously affect the purchasing decisions of consumers of First Media Internet Services, which means that the consumers to buy are based on their brand image, price and word of mouth. If the brand image, price and word of mouth are bad, then consumers will not subscribe to First Media.

\section{Conclusion}

From the results of a study of 100 respondents related to the influence of word of mouth and brand image on the purchasing decision of Make Over cosmetic products in the city of Semarang, the conclusions can be drawn as follows:

1. Word of mouth (X1) partially has a significant influence on purchasing decisions (Y) for Make Over cosmetic products. Thus, the hypothesis stated that word of mouth influences the purchasing decision of Make Over cosmetic products can be accepted. 
2. Brand image (X2) partially has a significant influence on purchasing decisions (Y) for Make Over cosmetic products. Thus, the hypothesis stated that brand image influences the purchase decision of Make Over cosmetic products can be accepted.

3. Word of mouth (X1) and brand image (X2) simultaneously have a significant influence on purchasing decisions (Y) of Make Over cosmetic products. Therefore, the hypothesis stated that Word of mouth and brand image influences the purchasing decision of Make Over cosmetic products can be accepted.

\section{Suggestion}

Based on the results of the research and discussion above, the suggestions that can be given are:

\section{For Companies}

To the Make Over management for continue to maintain, improve the product quality and continue to reproduce more attractive product variants is not only add variants to make-up products, but can penetrate skincare products for facial treatments such as facial foam, toner, cleansing, moisturizer, sunscreen, body lotion, and etc. that there are tailored for all types of consumer skin. This is the aim of creating satisfaction with consumers therefore when consumers feel satisfied when using a product will provide positive word of mouth to others. It is hopefully that a positive word of mouth will influence consumers' decisions to make repeat purchases and bring a new customer.

To enhance the positive brand image of Make Over in the minds of the public, Make Over management can encourage marketing activities by carrying out various digital or online marketing activities. By making or uploading various videos, contributing articles and similar to content related to cosmetics. Such as, the tutorial on using make-up correctly by using the Make Over product as a visual aid. Campaigning for Make Over products is halal, natural-based and free animal testing to instill the mind in consumers that Make Over is a product that is safe, environmentally friendly and cares for animals. Collaborate with talented young designers at home and overseas as official makeup partners. Perform various social and humanitarian activities in the name of Make Over. Moreover, it can be conducted by doing and maximizing marketing activities on social media such as Instagram. Therefore, it is hoped that a positive brand image continues to be embedded in the minds of consumers, If the company already has a positive image, it is expected to encourage consumers to make purchasing decisions on Make Over products.

2. For further research

It is expected that further researchers can conduct research with other variables that can influence purchasing decisions. Moreover, it can conduct research in cities outside Semarang to obtain research results with a broader scope.

\section{Research Limitation}

Can conduct research, there are weaknesses and limitations experienced by the authors where this study has limitations using only 2 (two) variables, while there are many other factors that influence consumer purchasing decisions such as promotion, product quality, celebrity endorser, product attributes and many the other.

\section{Citation information}

Kurniawati, N. I. (2020). Analysis of the influence of word of mouth and brand image on the decision to purchase cosmetics make over products in Semarang. Economics, Management and Sustainability, 5(2), 138-148. doi:10.14254/jems.2020.5-2.11.

\section{References}

Amrullah, A. R. and Agustin, S. (2016) 'Pengaruh Kualitas Produk Harga dan Citra Merek terhadap Keputusan Pembelian Honda Beat', Jurnal Ilmu dan Riset Manajemen Sekolah Tinggi Ilmu Ekonomi Indonesia (STIESIA) Surabaya ISSN: 2461-0593.

Andy Sernovitz; Seth Godin; Guy Kawaskaki (2012) Word of mouth marketing : how smart companies get people talking, Kaplan Publishing. 
Angio, I. (2013) 'Pengaruh Brand Image terhadap Keputusan Pembelian Motor Yamaha Mio Soul di Kota Gorontalo (Studi Kasus Pada PT. Hasjrat Abadi)', KIM Fakultas Ilmu Sosial, 1(1).

Bella, A. (2018) Potensi Gemuk Pasar Kosmetik Tanah Air, marketeers. Available at: https://marketeers.com/potensi-gemuk-pasar-kosmetik-tanah-air/ (Accessed: 12 March 2020).

Cooper, D. R. and Schindler, P. S. (2006) Metode Riset Bisnis. Jakarta: PT Media Global Edukasi.

Farida, L. and Ristiawan, D. (2015) 'Pengaruh Citra Merek (Brand Image) terhadap Pengambilan Keputusan Pembelian Sepeda Motor Suzuki Satria Fu 150 Cc di Kota Pekanbaru (Studi Kasus pada Konsumen PT. Riau Jaya Cemerlang)', Jurnal Online Mahasiswa Fakultas Ilmu Sosial dan Ilmu Politik Universitas Riau.

Hasan, A. (2010) Marketing dari Mulut ke Mulut Word of Mouth Marketing. Yogyakarta: Media Presindo.

indonesia-investments (2018) Entertainment in Jakarta, indonesia-investments. Available at: https://www.indonesia-investments.com/business/working-living/entertainment-injakarta/item298 (Accessed: 12 June 2019).

Joesyiana, K. (2018). Pengaruh word of mouth terhadap keputusan pembelian konsumen pada media online shop shopee di pekanbaru. Valuta.

Keller, K. . K. (2008) Strategic Brand Management: building, measuring, and managing brand (4th edition), Pearson/Prentice Hall. doi: 10.2307/1252315.

Kotler (2013) Manajemen Pemasaran Jilid 2, Penerbit Erlangga.

Kotler, P., \& and Amstrong, G. (2008) Prinsip-Prinsip Pemasaran. 12th ed. Jakarta: Erlangga.

Kotler, P. \& K. L. K. (2011) 'Manajemen pemasaran jilid 1, edisi Ketiga belas, Terjemahan Bob Sabran.', Jakarta: Erlangga. doi: 10.1177/0022022111434597.

Kotler, P. and Armstrong, G. (2018) Principle of Marketing, Principles of Marketing.

Kotler, P. and Keller, K. L. (2009) Manajemen pemasaran Jilid 1, Jakarta.

Molinari, L. K., Abratt, R. and Dion, P. (2008) 'Satisfaction, quality and value and effects on repurchase and positive word-of-mouth behavioral intentions in a B2B services context', Journal of Services Marketing. doi: 10.1108/08876040810889139.

Moniharapon, S., Lapian, J. and Lotulung, S. C. (2015). Pengaruh kualitas produk, harga, dan wom (word of mouth) terhadap keputusan pembelian handphone evercoss pada cv.tristar jaya globalindo manado. Jurnal Riset Ekonomi, Manajemen, Bisnis dan Akuntansi. doi: 10.35794/emba.v3i3.9614.

Mowen, John C. and Minor, M. (2002) Prilaku konsumen, Organization. doi: 10.1016/j.materresbull.2010.09.021.

Musay, F. (2013). Pengaruh brand image terhadap keputusan pembelian (survei pada konsumen kfc kawi malang). Jurnal Administrasi Bisnis S1 Universitas Brawijaya.

Nuraeni, N. (2014). Pengaruh Kualitas Produk dan Word Of Mouth Communication Terhadap Keputusan Pembelian (Studi Pada Toko Emas Ari Jaya). Jurnal Sketsa Bisnis, 1(2). doi: https://doi.org/10.35891/jsb.v1i2.73.

Peter, P. J. and Olson, J. C. (2013). Perilaku Konsumen dan Strategi Pemasaran, Salemba Empat.

Rangkuti, F. (2009). Strategi Promosi yang Kreatif dan Analisis Kasus Integrated Marketing Communication. Jakarta: PT. Gramedia Pustaka Utama.

Sagita, F. E. et al. (2012). Pengaruh brand image dan harga terhadap keputusan pembelian ulang produk kentucky fried chicken (KFC) di cabang basko grand mall oleh mahasiswa universitas negeri padang', Universitas Negeri Padang.

Schiffman, L. and Kanuk, L. L. (2008). Perilaku konsumen. Jakarta: Indeks. 
Simbolon, H. (2015) Pengaruh Brand Image I-Phone terhadap Keputusan Pembelian pada Mahasiswa FISIP USU. University of Sumatera Utara Institutional.

Sugiyono (2014) Metode Penelitian Bisnis. Bandung: Alfabeta.

Tampinongkol, V. M. and Mandagie, Y. (2018). Analisis pengaruh word of mouth, kualitas produk dan brand image terhadap keputusan pembelian sepatu converse di manado town square. Jurnal EMBA: Jurnal Riset Ekonomi, Manajemen, Bisnis dan Akuntansi. doi:10.35794/emba.v6i4.20930.

Wicaksono, M. and Seminari, N. (2016). Pengaruh iklan dan word of mouth terhadap brand awareness traveloka. None.

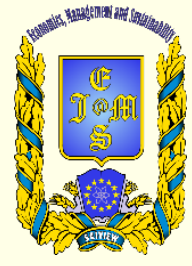

( 2 2016-2020, Economics, Management and Sustainability. All rights reserved.

This open access article is distributed under a Creative Commons Attribution (CC-BY) 4.0 license.

You are free to:

Share - copy and redistribute the material in any medium or format Adapt - remix, transform, and build upon the material for any purpose, even commercially.

The licensor cannot revoke these freedoms as long as you follow the license terms.

Under the following terms:

Attribution - You must give appropriate credit, provide a link to the license, and indicate if changes were made.

You may do so in any reasonable manner, but not in any way that suggests the licensor endorses you or your use.

No additional restrictions

You may not apply legal terms or technological measures that legally restrict others from doing anything the license permits.

Economics, Management and Sustainability (ISSN: 2520-6303) is published by Scientific Publishing House "CSR", Poland, EU and Scientific Publishing House "SciView", Poland

Publishing with JEMS ensures:

- Immediate, universal access to your article on publication

- High visibility and discoverability via the JEMS website

- Rapid publication

- Guaranteed legacy preservation of your article

- Discounts and waivers for authors in developing regions

Submit your manuscript to a JEMS at http://jems.sciview.net or submit.jems@sciview.net

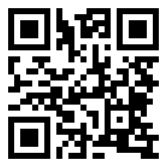

